\title{
徳島大学皮膚科における薬疹の統計
}

德岛人学医学部皮海科教晊（主任：武山克之教授）

麻野誠一期・榎木充邦・重見文雄

\section{Statistical Survey of Patients with Drug Eruption at Department of Dermatology, Tokushima University} (1963-1977)

\author{
Seiichiro ASANO, Mitsukuni ENOMOTO \\ and Fumio SHIGEMI \\ Department of Dermatology, Schuol of Medicine, Tokushima University \\ Tokushima. Japan (Director: Prof. K. Takeda)
}

\section{はじめに}

わが国が世界の最長寿国になつたととが報じられて月 も浅い。長寿国になりえた要因のひとつに医療水準の向 上があげられ，数多くの有用な楽剂の登場む大きな役揢 りをはたしていると思われる。他方、楽戍の副作用があ とをたたない現状であり，近頃の薬疹の統計的観察は一 致して薬蓼患者の增加を指摘している。

このたび，われわれは昭和 39 年 52 年の間に，徳島

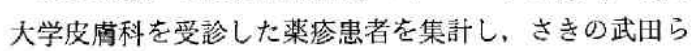
の報告" から昭和 38 年の蒋瑢患者をくり入れて，15年 間の薬疹患者について統計的に観察したので報告する。

\section{対象と観察方法}

炤和 38 年 1 月から昭和 52 年 12 月までの 15 年間に, 德鳥大学皮清科を訪れた患者総数は 50,452 例であつた。 このうち, 問診, 検查, 臨床症状などから蒋疹と診断さ 九た 927 例を対象として, 年次別, 月別, 性別, 年令別 の変動を観察し, 各症例の発疹型, 原因薬剂についてお 検討した。

発疹型の分類については種々の提案があるが，ててで は細かい分類を避けて, 固定疹型, 沉発疹型, TEN (to-

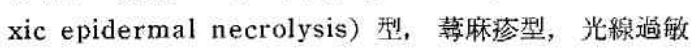
型, 痤痏型に分け, 上記のいずれにむ属さないものをを の他とした。

原因薬剂の決定は誘発試験，貼布試験などで確認した 症例もあるが，問龄を重視した症例も多い。医師により 処方された楽剂については可能なかぎり直接処方内容を 照会し，原因薬剂を追求した。また，複数の薬剤が使用 され，いずれとも判定しえなかつた場合は原因薬剂不明
とした。

\section{観 察 結 果}

1. 年次別患者数：昭和 38 年から 52 年 までの 15 年 間の薬掺患者数の年次別変動では, 昭和 43 年にピーク を形成し，ついて炤和 50 年に第 2 の山がある。との 15 年間を便宜上, 5 年ごとに前・中・後期に 3 区分して観 察する之, 昭和 38 年 42 年の 前期 5 年間は薬疹忠者数 34 例 38 例で, 対外来患者百分率は $1.07 \% \sim 1.46 \%$ の 間にあり, 平均 $1.26 \%$ と 15 年間のうち発生頻度はすつ とも低い。中期 5 年間では昭和 43 年飞 93 例, $2.91 \%$ と 急増し, 昭和 45 年にふたたび前 5 年間の頻度に近づき, 大きく変動するが, 平均発生頻度 $2.25 \%$ で最高であつ た。後期 5 年間も前期より高頻度 (平均 $1.97 \%$ ) であ つた。最近の 10 年間は前 5 年間より薬疹患者の頻度は 增加している。なお，全年度を通じて薬疹患者数と外来 患者総数にたいする百分率はほほ平行している(第 1 表, 第 1 図)。

今回の15年間の薬疹患者数をさきの当科の15年間（昭 和 24 年 38 年) の集計 ${ }^{1}$ と比較してみると, 今回の症 例数は 927 例で, 対外来患者白分率は $1.84 \%$ となり, さきの $0.63 \%$ \%をく上回つている。昭和 38 年が重複 しているととを考虑しても，最近 15 年間に蒋翏患者の 増加がめだつ（百分率であ約 3 倍)。

硧口ら² が過去 60 年間の蒋疹の発生の推移に 3 つの 大きな波をあげ，第 1 波はヨード・ブロム疹時代（明治 末期）、第 2 波はサルバルサン奖時代（昭和 12 年〜 17 年), 第 3 波は昭和 36 年以降の多種類の薬剂による蒋疹 時代であるとし「てとしばらくは下降線をたどるとと はあるまい」と述べているが，その予言が 10 年以上を 


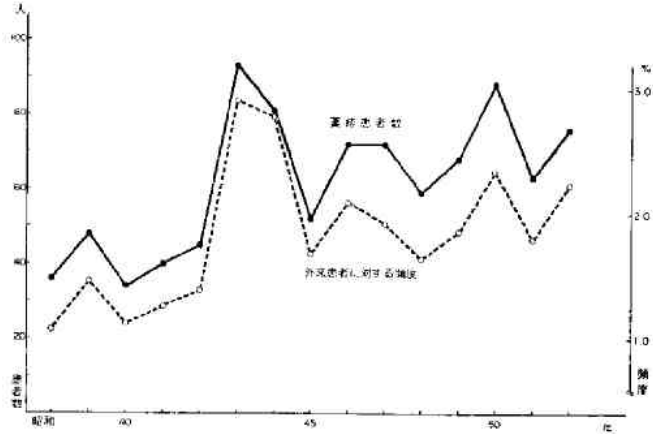

第1図年度别薬疹患者数むよア゙その頻度

第1表 年次別箱疹患者数

\begin{tabular}{|c|c|c|c|c|c|c|}
\hline \multirow{2}{*}{$\begin{array}{l}\text { 年 } \\
38\end{array}$} & \multirow{2}{*}{$\begin{array}{l}\text { 外来患者 } \\
\text { 給 数 }\end{array}$} & \multicolumn{3}{|c|}{ 薬疹患者数 } & \multirow{2}{*}{\multicolumn{2}{|c|}{$(9.8)$}} \\
\hline & & 男 & 女 & 計 & & \\
\hline $\begin{array}{l}38 \\
39 \\
40 \\
41 \\
42\end{array}$ & $\begin{array}{l}3378 \\
3281 \\
3042 \\
3176 \\
3233\end{array}$ & $\begin{array}{l}12 \\
21 \\
15 \\
24 \\
22\end{array}$ & $\begin{array}{l}24 \\
27 \\
19 \\
16 \\
23\end{array}$ & $\begin{array}{l}36 \\
48 \\
34 \\
40 \\
15\end{array}$ & $\begin{array}{l}1.07 \\
1.46 \\
1.12 \\
1.26 \\
1.39\end{array}$ & $\begin{array}{l}\text { 平厸 } \\
\quad \text { l. } 26\end{array}$ \\
\hline $\begin{array}{l}43 \\
44 \\
45 \\
46 \\
47\end{array}$ & $\begin{array}{l}3197 \\
2901 \\
3102 \\
3441 \\
3750\end{array}$ & $\begin{array}{l}41 \\
31 \\
22 \\
27 \\
30\end{array}$ & $\begin{array}{l}52 \\
50 \\
30 \\
45 \\
42\end{array}$ & $\begin{array}{l}93 \\
81 \\
52 \\
72 \\
72\end{array}$ & $\begin{array}{l}2.91 \\
2.79 \\
1.68 \\
2.09 \\
1.92\end{array}$ & $\begin{array}{l}\text { 平均 } \\
2.25\end{array}$ \\
\hline $\begin{array}{l}48 \\
49 \\
50 \\
51 \\
52\end{array}$ & $\begin{array}{l}3606 \\
3665 \\
3755 \\
3514 \\
3411\end{array}$ & $\begin{array}{l}21 \\
29 \\
38 \\
26 \\
35\end{array}$ & $\begin{array}{l}38 \\
39 \\
50 \\
37 \\
41\end{array}$ & $\begin{array}{l}59 \\
68 \\
88 \\
63 \\
76\end{array}$ & $\begin{array}{l}1.64 \\
1.86 \\
2.34 \\
1.79 \\
2.23\end{array}$ & $\begin{array}{l}\text { 平.均 } \\
1.97\end{array}$ \\
\hline it & 50452 & 394 & 533 & 927 & 平均 & 1. 84 \\
\hline
\end{tabular}

経た今日でもくつがえされていない。

2. 初診月別患者数：15 年間の薬疹患者の 発生を初 㟝月別に此較する上，7月が 115 例とすつとも多く，11 月が 43 例であつとす少なかつた。10月〜12月に蒋疹患 者数方少ない僋向にあるのは, 諸家の報告 ${ }^{324)}$ とも一致 するが，その要因は明らかでい（第 2図）。

3. 性別：薬珍患者の性別は, 男 394 例, 女 533 例 で，男女比が 1: 1.35 と女洛く(第 1表)，諸家の 報告2046) とことなる。しかし，外来患者の性差む，男 21,119 例, 女 29,333 例, 男女比 1: 1.39 と女が多く, 発生頻度でみれば，男 $1.87 \%$ ，女 $1.82 \%$ となり，ほと んど差はないといえよう。

4. 年令: 15 年間（昭和 38 年 52 年）の楽疹患者の 年令分布は 20 才代が 197 例, 30 才代が 192 例と 20 才 40才に好発し全体の約 4 割を占める（第 2 表，第 3 図)。 この 15 年間を 5 年でとに 3 区行すると, 前期（昭和 38

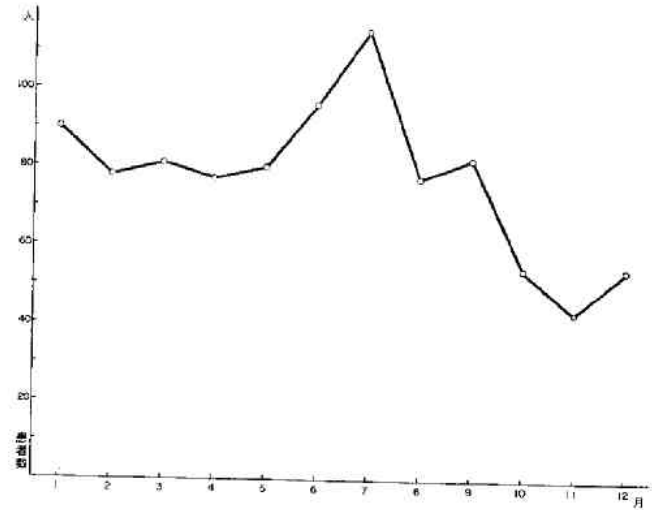

第2図初部月別楽疹患者数

第 2 表 藥疹0年合別岕者数

\begin{tabular}{|c|c|c|c|c|c|c|c|c|}
\hline 7 & & $\begin{array}{l}1 \\
\sim 20\end{array}$ & $\stackrel{21}{\sim 30}$ & $\stackrel{31}{\sim 40}$ & $\stackrel{41}{\sim} 50$ & $\stackrel{51}{\sim 60}$ & $\mid 61$ & 71 - \\
\hline $\begin{array}{l}38 \\
39 \\
40 \\
41 \\
42\end{array}$ & $\begin{array}{l}0 \\
5 \\
4 \\
2 \\
4\end{array}$ & 6 & $\begin{array}{r}7 \\
8 \\
7 \\
12 \\
8\end{array}$ & $\begin{array}{l}12 \\
18\end{array}$ & $\begin{array}{r}7 \\
6 \\
5 \\
4 \\
10\end{array}$ & $\begin{array}{l}5 \\
5 \\
1 \\
4 \\
5\end{array}$ & $\begin{array}{l}2 \\
1 \\
1 \\
1 \\
4\end{array}$ & 1 \\
\hline $\begin{array}{l}43 \\
44 \\
45 \\
46 \\
47\end{array}$ & $\begin{array}{l}5 \\
7\end{array}$ & $\begin{array}{r}9 \\
17 \\
6 \\
4 \\
10\end{array}$ & $\begin{array}{r}9 \\
20 \\
13\end{array}$ & 13 & $\begin{array}{r}15 \\
7 \\
12 \\
8 \\
10\end{array}$ & $\begin{array}{r}6 \\
8 \\
3 \\
4 \\
10\end{array}$ & $\begin{array}{r}7 \\
0 \\
6 \\
11 \\
7\end{array}$ & \\
\hline $\begin{array}{l}48 \\
49 \\
50 \\
51 \\
52\end{array}$ & $\begin{array}{r}6 \\
8 \\
13 \\
2 \\
3\end{array}$ & $\begin{array}{l}7 \\
7 \\
9 \\
7 \\
9\end{array}$ & $\begin{array}{l}20 \\
15 \\
13\end{array}$ & $\begin{array}{r}11 \\
12 \\
8\end{array}$ & $\begin{array}{r}5 \\
13 \\
10 \\
7 \\
12\end{array}$ & $\begin{array}{r}10 \\
9 \\
12 \\
8 \\
17\end{array}$ & $\begin{array}{r}10 \\
5 \\
6 \\
7 \\
7\end{array}$ & \\
\hline 計 & 77 & 110 & 197 & 192 & 131 & 107 & 75 & 38 \\
\hline $\begin{array}{l}\text { 出 } \\
\text { 卉 }\end{array}$ & $\begin{array}{l}34 \\
43\end{array}$ & $\begin{array}{l}41 \\
69\end{array}$ & $\begin{array}{r}81 \\
116\end{array}$ & $\begin{array}{r}78 \\
114\end{array}$ & $\begin{array}{l}52 \\
79\end{array}$ & $\begin{array}{l}42 \\
65\end{array}$ & $\begin{array}{l}40 \\
35\end{array}$ & $\begin{array}{l}26 \\
12\end{array}$ \\
\hline
\end{tabular}

年〜42 年）は 30 才代が 57 例ともつとも頻度が高いが， 中期（昭和 43 年 47 年）抒上び 後期（昭和 48 年 52 年）は20才代にそれぞれ 86 例，69例と頻発している。 また，前期は 30 才代をピークとする急帰なピラミッド 型であるのに比し，中期は 20 才代，30才代がピークを つくり，後期ではピークが 20 才代に移行するととむに, ひろく各年令層注患者が分布して差が少なくなつている (第 4 図)。乙れは 50 才以上の高年令居に打ける 楽疹患 者数の增加にほかならず，乙の傾向は旗口ら²，北村 ら16) の報告と一致する。今後, 高令者人口の增加とと あに，この倾向は強まり，薬翏患者が各年令層にわたつ て增加することを予想させる。 


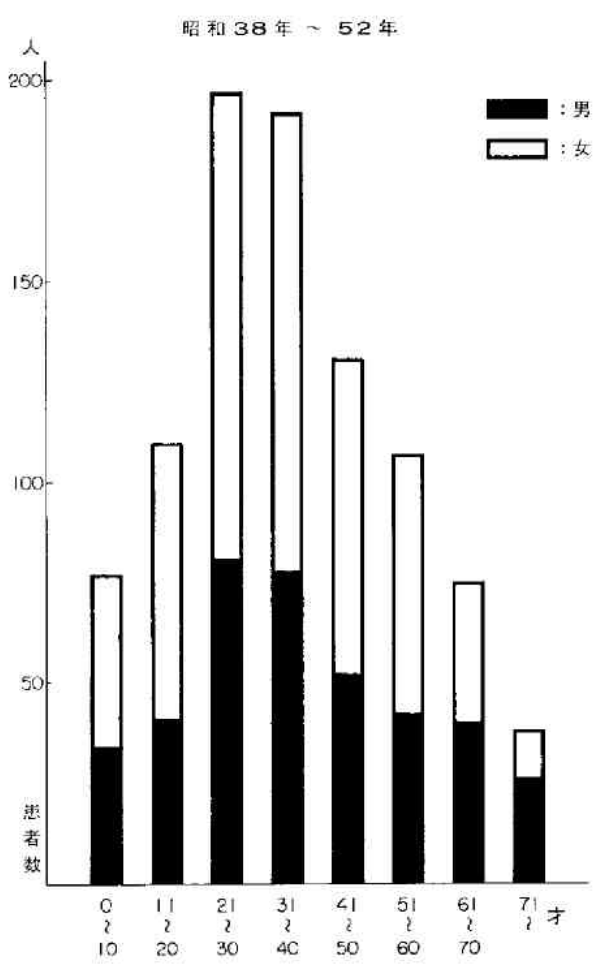

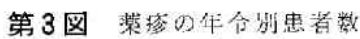

5. 発疹型: 薬剂による皮点の反応形式は多種多様で あるから薬疹の発疹型はきわめて多彩であるが，全身に 汎発するものの多くはアレルギー性の発症機転をとり，

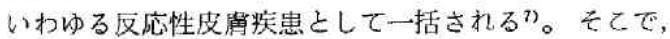

第 3 表 嬊疹の発疹型別患者数

\begin{tabular}{|c|c|c|c|c|c|c|c|}
\hline 型品 & $\begin{array}{l}\text { 固定 } \\
\text { 沴型 }\end{array}$ & $\begin{array}{l}\text { 沉発 } \\
\text { 落㨐 }\end{array}$ & TEN & 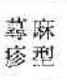 & $\begin{array}{l}\text { 粦線 } \\
\text { 遗敏型 }\end{array}$ & 座瘖型 & その型 \\
\hline 38 & 12 & 13 & 0 & 1 & 4 & 2 & 4 \\
\hline 39 & 20 & 13 & 1 & 0 & 0 & 7 & 7 \\
\hline 40 & 13 & 12 & 0 & 0 & 0 & 8 & 1 \\
\hline 41 & 15 & 11 & 0 & 3 & 0 & 8 & 3 \\
\hline 42 & 12 & 18 & 0 & 1 & 0 & 5 & 9 \\
\hline 43 & 22 & 44 & 0 & 1 & 2 & 9 & 15 \\
\hline 44 & 13 & 36 & 1 & 2 & 1 & 15 & 13 \\
\hline 45 & 13 & 23 & 1 & 1 & 0 & 7 & 7 \\
\hline 46 & 14 & 32 & 0 & 3 & 2 & 4 & 17 \\
\hline 17 & 8 & 41 & 1 & 3 & 1 & 14 & 4 \\
\hline 48 & 9 & 26 & 1 & 0 & 3 & 3 & 17 \\
\hline 49 & 11 & 40 & 0 & 3 & 1 & 4 & 9 \\
\hline 50 & 12 & 44 & 0 & 5 & 7 & 14 & 6 \\
\hline 51 & 7 & 34 & 0 & 4 & 2 & 6 & 10 \\
\hline 52 & 6 & 40 & 0 & 2 & 1 & 14 & 13 \\
\hline 計 & 187 & 427 & 5 & 29 & 24 & 120 & 135 \\
\hline
\end{tabular}

発疹型别に頻度をみる上，汎発疹型が 427 例で，2位の 固定疹型 187 例老はるかに上回つており，上くに昭和 43年以降この傾向がめだち, 北村らの の報告む同槏の傾

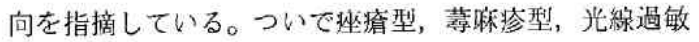
型などの順で続くが，その他に属する症列も墦えてきて いる。最近の薬疹の発疹型はますます多様化の傾向にあ ることをうかがうせる(第 3 表)。

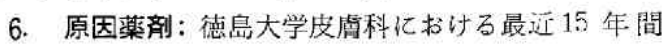
の薬疹患者を原因楽剂別に分けると, 解熱鎮痛剂が 163 例でむつとむ多く，ついで抗生物買 147 例，以下ステロ イド昘 85 例, 感莦薬 69 例, 精神病蒋 53 例, 玾結核剂 29 例, 降圧放 24 例, サルファ剂 13 例の順に続く。年
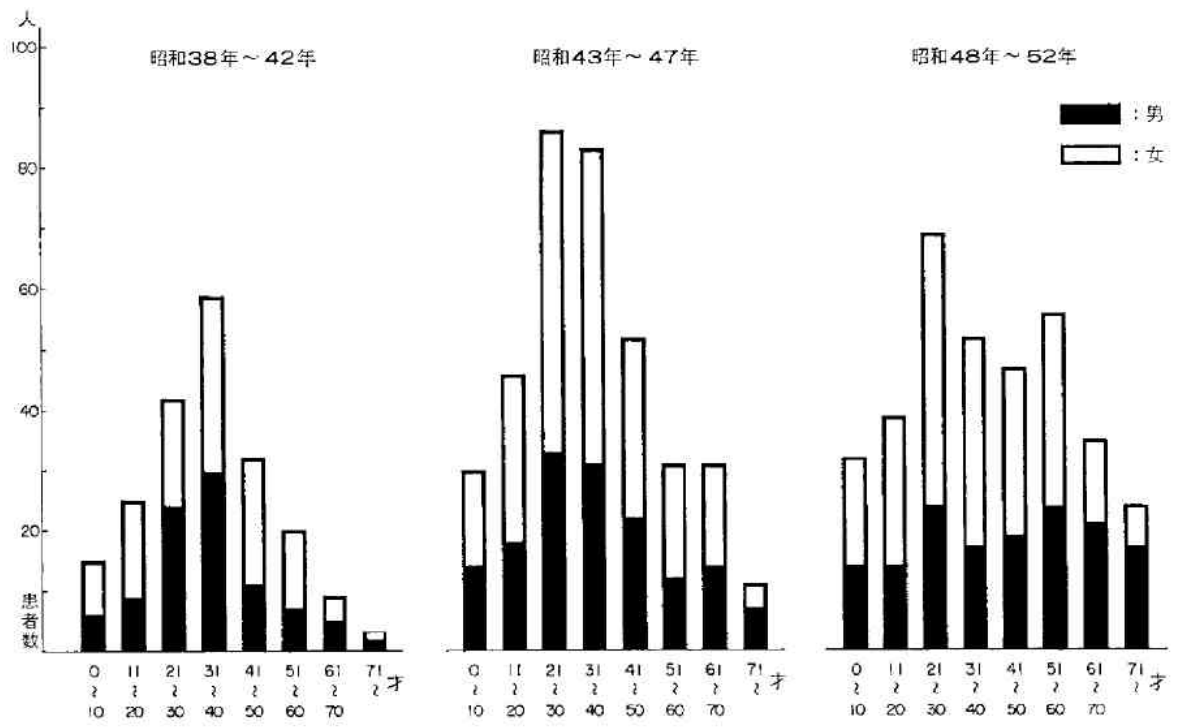

第 4 図

蒋疹 0 年令別患者数 
第 4 表薬疹 D原圆菜削別患者数

\begin{tabular}{|c|c|c|c|c|c|c|c|c|c|c|c|}
\hline 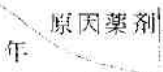 & 抗址物質 & $\begin{array}{c}サ ル フ ァ \\
\text { 剂 }\end{array}$ & 抗絬核剂 & 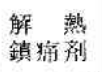 & 感冒薬 & 降压剂 & 精神病葆 & ス & その他 & 不 明 & 計 \\
\hline 38 & 2 & 0 & 0 & 12 & 1 & 5 & 1 & 2 & 3 & 10 & 36 \\
\hline 39 & 0 & 1 & 2 & 18 & 3 & 0 & 0 & 3 & 6 & 15 & 48 \\
\hline 40 & 0 & 2 & 0 & 10 & 3 & 0 & 0 & 7 & 2 & 10 & 34 \\
\hline 41 & 1 & 1 & 2 & 6 & 6 & 0 & 1 & 8 & 3 & 12 & 40 \\
\hline 42 & 3 & 1 & 2 & 13 & 2 & 1 & 5 & 4 & 2 & 12 & 45 \\
\hline 43 & 11 & 1 & 1 & 17 & 6 & 1 & 5 & 6 & 6 & 39 & 93 \\
\hline 44 & 10 & 4 & 2 & 8 & 6 & 1 & 6 & 10 & 7 & 27 & 81 \\
\hline 45 & 7 & 0 & 2 & 11 & 9 & 0 & 3 & 6 & 0 & 14 & 52 \\
\hline 46 & 19 & 0 & 3 & 17 & 1 & 1 & 5 & 2 & 6 & 18 & 72 \\
\hline 47 & 27 & 0 & 3 & 8 & 2 & 0 & 3 & 9 & 6 & 14 & 72 \\
\hline 48 & 8 & 1 & 1 & 5 & 6 & 4 & 5 & 3 & 5 & 21 & 59 \\
\hline 49 & 16 & 0 & 4 & 10 & 6 & 1 & 4 & 0 & 9 & 18 & 68 \\
\hline 50 & 15 & 2 & 1 & 14 & 9 & 5 & 6 & 13 & 3 & 20 & 88 \\
\hline 51 & 16 & 0 & $i$ & 9 & 6 & 3 & 3 & 5 & 8 & 12 & 63 \\
\hline 52 & 12 & 0 & 5 & 5 & 3 & 2 & 6 & 7 & 8 & 28 & 76 \\
\hline 計 & 147 & 13 & 29 & 163 & 69 & 24 & 53 & 85 & $7 \leq$ & 270 & 927 \\
\hline
\end{tabular}

次別てはあいつぐ抗生物筫の開発とその使用頻度の增加 につれて抗生物質を原因薬郕とする薬疹患者加增加傾向 にあるのは当然之思われるが，ほかに，䊑神病楽が昭社 43 年ころより，降王剂が昭和 48 年ころよりかなり增关 ているこ上が注目される（第 4 表）。

\section{ま と め}

1) 昭和 38 年から 52 年までの 15 年間飞德岛大学皮 唐科を受診した蒋疹患者数は 927 例で外来患者数 50,452 例にたいする百分泝は 1.8496 であつた。

2)初紾月別に薬掺患者数をみると，7月をピークに 1月加ら9月に加汁て多く, 10 月から 12 月に少ない。

3) 薬疹患者を年命別飞かけると、20才代がもつ之 も多く, 20 才から 40 才が約 4 割を占めるが, 近年, 高 年令層での増加がめだち，各年令層間の差は減少してい 页。

4）発疹型では沉発疹型が多く，固定疹型をはるかに 上回つている。また，発疹の多椂化倾向をうかがわせ
る。

5）原因薬剂では解熱鎮痛剂と抗生物質が多く，近 年, 精神病薬之降圧剤による薬疹の增加が注目される。

(稿を終るにあたり，御指導，御校閲をいたたいた武 因克之教授に感謝いたします。)

\section{文献}

1）武田克之・他：皮と袐. 26：789，1964.

2）确口謙太郎・他：皮と泌. 28: 29, 1966.

3) 小嶋理一儀保之彦: 皮消臨本. 10:449, 1965 .

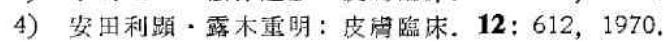

5) 满口周策：皮清㯺床, 9: 99, 1967 .

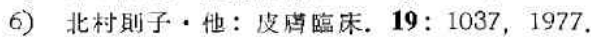

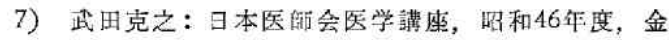
原出版, 1973, p. 263.

$$
\text { (明和53年 } 7 \text { 月18日 受付・特揭) }
$$

別刷請求先: 7770 德离方蔵本町3-18-15 德島大学学学部皮成科教室 麻野誠一郎 